\title{
Peningkatan Efikasi Diri Matematika melalui Metode Belajar Mind Map
}

\author{
Gita Aulia Nurani ${ }^{1}$, Asmadi Alsa ${ }^{2}$ \\ ${ }^{1}$ Fakultas Psikologi, Universitas Muhammadiyah Surakarta, Indonesia \\ ${ }^{2}$ Fakultas Psikologi, Universitas Gadjah Mada, Yogyakarta, Indonesia \\ Program Studi Doktoral Ilmu Psikologi, Universitas Persada Indonesia-Y.A.I. Jakarta, Indonesia \\ e-mail: gita.nurani@ums.ac.id
}

\begin{abstract}
This study aims to test empirically the effect of the mind maps visual learning method on increasing the self-efficacy of learning mathematics in junior high school students. The research design used a quasi-experimental design with the one-group pretest-posttest design. The research subjects were collected using a non-random purposive sampling technique with 22 students who had moderate to low self-efficacy scores. Data collection used the mathematics self-efficacy scale, and data analysis using repeated analysis of variance. The results showed that there was a difference in the average score of learning mathematics self-efficacy between pre-test and post-test. This finding may indicate that the mind maps visual learning method has a positive effect on increasing the self-efficacy of learning mathematics in junior high school students. The increase in the average self-efficacy score in the generalization dimension was 5.8 points, the level dimension was 4.5 points, and the strength dimension was 3.1 points.
\end{abstract}

Keywords: visual learning style, mind map, mathematics self-efficacy

\begin{abstract}
Abstrak
Penelitian ini bertujuan untuk menguji secara empirik pengaruh metode belajar visual mind map terhadap peningkatan efikasi diri belajar Matematika pada siswa SMP. Rancangan penelitian menggunakan desain eksperimen kuasi one-group pretest-posttest design. Subjek penelitian diambil dengan teknik non random purposive sampling berjumlah 22 siswa yang memiliki skor efikasi diri sedang hingga rendah. Pengumpulan data menggunakan skala efikasi diri Matematika, dan analisis datanya menggunakan analisis varian amatan ulang. Hasil penelitian menunjukkan terdapat perbedaan rata-rata skor efikasi diri belajar Matematika dengan skor pretest yang lebih rendah dibandingkan skor posttest. Ini berarti metode belajar visual mind map berpengaruh positif terhadap peningkatan efikasi diri belajar Matematika siswa SMP. Peningkatan rata-rata skor efikasi diri pada dimensi generalization sebesar 5.8 poin, dimensi level sebesar 4.5 poin, dan dimensi strength sebesar 3.1 poin.
\end{abstract}

Kata Kunci: gaya belajar visual, mind map, efikasi diri Matematika

\section{Pendahuluan}

Keyakinan seseorang dalam mempelajari sesuatu dapat membawa pengaruh pada keberhasilan belajar terutama bagi siswa sekolah. Menurut AlMehsin (2017) efikasi diri membantu siswa dalam membuat keputusan belajar secara efektif. Keyakinan tersebut dapat bersumber dari sisi internal ataupun eksternal siswa. Keyakinan yang bersumber dari dalam diri disebut dengan self-efficacy atau efikasi diri. Efikasi diri dapat diartikan sebagai keyakinan diri terhadap kemampuan yang dimiliki untuk menyelesaikan sesuatu (Warner \& French, 2020). Penelitian sebelumnya menyebutkan efikasi diri memiliki pengaruh yang kuat dalam kesuksesan akademik seseorang (Ahmad \& Triantoro, 2013; Köseoğlu, 2015; Basith dkk., 2020; Warsihna dkk., 2021). Siswa sekolah yang memiliki efikasi diri tinggi akan menunjukkan keterampilan dalam pelajaran dengan baik pula (Kudo \& Mori, 2015). 
Kelancaran proses pembelajaran Matematika pada level Sekolah Menengah Pertama (SMP) dapat ditunjang oleh efikasi diri siswa, dalam hal ini efikasi diri siswa dalam belajar mata pelajaran Matematika. Matematika seringkali menjadi salah satu mata pelajaran yang dianggap sulit oleh siswa. Karakteristik materi yang dipenuhi oleh angka, garis, tabel, diagram, dan hitungan membatasi siswa untuk berusaha menampilkan potensi terbaiknya (Adhikari, 2020). Salah satu faktor yang dapat memengaruhi efikasi diri siswa dalam mempelajari Matematika adalah dukungan dari lingkungan belajar, yaitu guru (Martin \& Rimm-Kaufman, 2015). Guru memiliki dampak yang kuat karena mengenalkan materi dengan menggunakan berbagai metode belajar. Hal tersebut diharapkan dapat memfasilitasi pemahaman siswa di sekolah.

Perspektif sosial kognitif memandang bahwa perilaku mengerjakan soal Matematika yang dilakukan siswa, dipengaruhi oleh determinan individu yang berupa pikiran atau perasaan yang muncul terkait Matematika. Selain itu ada pula peran dari faktor lingkungan berwujud metode mengajar yang digunakan guru (Bandura, 1997). Siswa melihat guru menggunakan teknik mind maps dalam mencatat pelajaran kemudian menerapkan hal tersebut adalah bagian dari vicarious experiences.

Hasil diskusi kelompok pada siswa SMP yang dilakukan oleh peneliti pada preliminary study menunjukkan bahwa ada beberapa alasan yang membuat siswa merasa sulit mempelajari Matematika, yaitu: (1) Tidak yakin dapat menyelesaikan soal. Siswa sudah merasa tidak percaya diri karena pengalaman sejak sekolah dasar mempelajari Matematika adalah hal yang sulit; (2) Sulit merasa terikat dengan tugas Matematika. Siswa merasa tugas Matematika membosankan dan senang ketika tidak ada pekerjaan rumah; (3) Tidak ada antisipasi kegagalan. Meskipun mengetahui bahwa soal Matematika cukup sulit, siswa tidak berusaha lebih untuk mengubah kondisi tersebut; dan (4) Merasa gagal dalam Matematika adalah hal biasa. Siswa melihat orang di sekitarnya menganggap sepele jika mendapat nilai buruk dalam Matematika.

Keempat hasil diskusi tersebut memunculkan fakta bahwa keraguan atau ketidakyakinan dalam diri siswa adalah faktor penghambat terbesar dalam mempelajari Matematika. Sebuah penelitian yang dilakukan oleh Cheema (2018) turut menguatkan pernyataan tersebut. Peneliti menyebutkan bahwa efikasi diri siswa sangat terkait dengan literasi Matematika. Artinya, siswa yang memiliki keyakinan dapat mengerjakan soal Matematika cenderung ingin mempelajari rumus hitungan lebih lanjut.

Siswa dengan efikasi diri rendah tercatat memiliki kecemasan menyelesaikan soal Matematika lebih tinggi (Siswanti \& Djalal, 2018; Joseph, 2019). Pada dasarnya efikasi diri tidak mencerminkan keterampilan yang dikuasai individu, melainkan keyakinan terkait kemampuan diri dalam berbagai situasi (Warner \& French, 2020). Keyakinan tersebutlah yang akan memotivasi siswa agar bisa mendapat hasil Matematika yang diharapkan (Hanifah dkk., 2020).

Individu mempersepsi efikasi diri yang tinggi sebagai dorongan agar dapat lebih konsisten dalam meraih tujuan konkret termasuk dari sisi nilai akademik. Hal tersebut terangkum dalam tiga dimensi efikasi diri yang dirumuskan oleh Bandura (1997), yaitu dimensi tingkatan (level), kekuatan (strength), dan generalisasi (generalization).

Dimensi level terkait dengan kesulitan tugas yang memengaruhi perilaku individu untuk mau mengerjakan atau tidak. Dimensi strength ialah kadar keyakinan seseorang terkait kemampuan yang dimiliki. Keyakinan yang rendah akan mendapatkan pengalaman tidak sesuai harapan pula. Terakhir, dimensi generalization merujuk pada keyakinan 
individu terhadap situasi khusus yang dihadapi. Ketiga dimensi tersebut pada langkah berikutnya digunakan untuk menyusun alat ukur guna mendapat informasi mengenai efikasi diri siswa yang berkaitan dengan pembelajaran Matematika di sekolah.

\section{Penelitian Adhikari} menyebutkan bahwa metode pengajaran guru dalam kelas membawa pengaruh pada tinggi atau rendahnya efikasi diri siswa. Metode belajar yang membosankan dan bersifat satu arah akan semakin menurunkan efikasi siswa sehingga tidak membantunya mendapat hasil akademik yang diharapkan. Terlebih lagi, pelajaran Matematika membutuhkan keterlibatan aktif, pemahaman konkret pada konsep dasar, serta pengalaman baru bagi individu yang mempelajarinya (Hughes \& Riccomini, 2011; Ampofo, 2019; Recber dkk., 2018).

Tiga kebutuhan pembelajaran Matematika tersebut dapat terfasilitasi melalui metode belajar visual. Model pembelajaran yang berpusat pada guru dengan tulisan monoton di papan tulis justru membuat siswa demotivasi (Snowman \& McCown, 2012). Siswa cenderung menginginkan gaya belajar yang berbeda dibanding pengalaman dari guruguru sebelumnya.

Gaya belajar visual dapat meningkatkan prestasi belajar siswa secara signifikan (Bire dkk., 2014; Sahabuddin dkk., 2018). Pembelajaran yang diselingi dengan warna, bentuk, dan gambar akan membuat siswa merasa tertarik dan dapat menyajikan pengalaman baru. Pengalaman baru tersebut nantinya dapat berperan sebagai pendorong efikasi diri.

Model pembelajaran visual melibatkan proses identifikasi materi, organisasi, dan analisa kritis pada satu rumus dengan rumus lain. Gaya belajar visual tersebut membawa keuntungan bagi siswa sehingga materi menjadi mudah dipahami dibanding buku teks. Selain itu pembelajaran visual memiliki pola yang lebih jelas dan mendukung proses memori serta mengingat kembali informasi yang telah dipelajari sebelumnya. Proses rehearsal atau mengulang kembali materi turut mendukung pemahaman siswa menjadi lebih baik.

Salah satu gaya belajar visual yang akrab dengan siswa adalah mind map. Penggunaan garis, warna, angka, karakter, simbol, dan gambar pada teknik tersebut membantu proses penyerapan materi pelajaran. Konsep mind map yang membebaskan penggunanya juga dapat memberi pengalaman baru bagi siswa sekaligus mengasah proses berpikir kreatif. Selain itu mind map juga dapat dengan mudah diterapkan dalam pelajaran Matematika (Loc \& Loc, 2020; Polat dkk., 2017).

Secara spesifik gaya belajar visual mind map dapat berpengaruh pada pengelolaan waktu dan usaha yang dikeluarkan siswa. Tugas rumah yang dikerjakan dengan visual mind map dapat berdampak positif pada orientasi tujuan intrinsik (Tanriseven, 2014). Dari sisi efektivitas pelaksanaan, perubahan metode belajar lebih mudah dilakukan jika dibandingkan dengan pemberian pelatihan khusus. Hal tersebut disebabkan guru dapat langsung mempraktikkan dalam kelas dengan keterampilan mengajar yang selama ini sudah dimiliki.

Konsentrasi siswa yang menggunakan metode belajar visual juga tercatat meningkat signifikan dibanding menggunakan metode lain ( $\mathrm{Lu} \&$ Yang, 2018). Sejalan dengan hal tersebut, gaya belajar visual memang menjadi pilihan bagi mayoritas siswa (Kurniati dkk., 2019). Penerapan gaya belajar visual juga cenderung mudah dan dapat menggunakan berbagai peralatan yang tersedia di sekolah seperti papan tulis, spidol warna, proyektor, visualisasi menggunakan laptop, dan sebagainya.

Gaya belajar visual dengan mind mapping terbukti dapat meningkatkan kreativitas dan prestasi siswa (Widiana \& 
Jampel, 2016). Penelitian lain juga membuktikan metode mind map yang diterapkan pada proses pembelajaran akan berdampak pada performansi akademik siswa secara signifikan (Adodo, 2013; Merchie \& Keer, 2013; Dhindsa dkk., 2011).

Pembelajaran Matematika dengan menggunakan metode mind map terbukti dapat meningkatkan kemampuan berpikir reflektif pada siswa SMP (Rochmad dkk., 2014). Lebih lanjut, mind map juga dapat meningkatkan pemahaman siswa serta menambah pengalaman belajar yang menyenangkan (Polat dkk., 2017; Loc \& Loc, 2020). Meskipun mind map telah terbukti dapat meningkatkan beberapa kemampuan dalam Matematika, namun belum ada yang mengungkap aspek psikologi efikasi diri pada siswa SMP dengan kerangka teori sosial kognitif.

Berdasarkan uraian tersebut, maka diajukan hipotesis penelitian bahwa metode belajar visual mind map berpengaruh positif terhadap efikasi diri Matematika pada siswa kelas VII SMP Negeri X.

\section{Metode Penelitian}

Penelitian ini menggunakan desain eksperimen kuasi the one-group pretestposttest design (Hastjarjo, 2019). Desain ini hanya menggunakan satu kelompok subjek dengan melakukan pengukuran efikasi diri Matematika sebanyak dua kali, yaitu sebelum subjek diberi pembelajaran dengan metode belajar visual mind map (pretest) dan setelah subjek diberi pembelajaran dengan metode belajar visual mind map (posttest). Jumlah peserta pada awal penelitian sebanyak 22 siswa. Selama proses penelitian, terdapat beberapa subjek yang tidak dapat mengikuti seluruh rangkaian kegiatan. Penyebab hal tersebut diantaranya adalah siswa tidak masuk sekolah karena sakit ataupun ijin sehingga melewatkan pertemuan pada pelajaran Matematika. Secara keseluruhan, subjek penelitian yang mengikuti kegiatan sejak awal intervensi hingga akhir sejumlah 18 siswa.

Teknik pengambilan sample penelitian menggunakan non random purposive sampling. Subjek diambil dari satu kelas VII SMP Negeri X dengan rerata nilai ujian Matematika terendah. Setelah itu dilakukan pengujian skor efikasi diri menggunakan skala. Kriteria subjek penelitian ini adalah siswa dengan skor efikasi diri kategori sedang hingga rendah serta mengikuti pelajaran Matematika dari awal hingga akhir penelitian. Skala efikasi diri digunakan sebagai seleksi awal subjek penelitian dengan skor kategori sedang hingga rendah. Sebelum proses penelitian dilakukan, para subjek diberi informed consent atau surat kesediaan sebagai salah satu syarat pelaksanaan penelitian.

Intervensi berlangsung saat pelajaran Matematika selama dua minggu dengan total 6 kali pertemuan. Pelajaran Matematika berlangsung tiga kali dalam seminggu yaitu setiap hari Senin, Rabu, dan Kamis. Setiap pertemuan memiliki durasi dua jam pelajaran atau sekitar 80 menit. Pada akhir pelajaran, guru selalu memberi tugas rumah sebagai salah satu bentuk latihan soal bagi siswa.

Instrumen penelitian yang digunakan ialah skala efikasi diri Matematika dengan jumlah item sebanyak 18 butir milik Qudsyi (2012). Alat ukur tersebut memiliki koefisien reliabilitas sebesar .797 sehingga dapat digunakan pada penelitian ini. Dimensi efikasi diri yang digunakan terdiri dari tiga yaitu level, strength, dan generalization. Dimensi level memiliki indikator keyakinan dapat mengerjakan soal Matematika tanpa bantuan dan mampu memahami materi dalam berbagai situasi (contoh item, "Ketika merasa tidak bisa mengerjakan soal Matematika, saya langsung meminta bantuan teman"). Indikator pada dimensi strength ialah keyakinan mendapatkan nilai di atas kriteria minimal serta keyakinan dalam mengerjakan soal Matematika yang rumit (contoh item, "Meski mendapat soal 
Matematika yang rumit, saya percaya bahwa saya mampu"). Dimensi terakhir yaitu generalization memiliki indikator inisiatif pengerjaan tugas dan melibatkan diri dalam kegiatan tugas Matematika (contoh item, "Saya mengerjakan tugas Matematika tanpa harus disuruh oleh orang lain sebelumnya").

Prosedur intervensi yang diberikan berupa penerapan metode belajar visual mind map pada pelajaran Matematika kelas VII SMP. Pedoman dilaksanakannya intervensi adalah modul yang disusun berdasarkan lima tahap utama pembelajaran sosial kognitif, yaitu komunikasi tujuan dan objektivitas, pemusatan perhatian, organisasi dan pemaknaan, penyampaian informasi materi, dan proses encoding long-term memory (LTM). Setiap tahapan intervensi tersebut mengandung landasan teori mind map dalam pembelajaran yang terdiri dari overview, preview, inview, dan review (Tee dkk., 2014).
Kelima tahapan intervensi yang menggunakan aspek penerapan pembelajaran dengan pendekatan sosial kognitif yang disusun Snowman dan McCown (2012), dapat dijelaskan sebagai berikut: (1) komunikasi tujuan dan objektivitas, berupa pemberian penjelasan tentang deskripsi, manfaat, dan tujuan metode belajar yang digunakan; (2) pemusatan perhatian, yaitu kemampuan untuk menarik perhatian siswa sehingga dapat fokus dan mengikuti proses pembelajaran secara aktif; (3) organisasi dan pemaknaan, artinya kemampuan dalam menghubungkan materi dan memahami ide-ide yang muncul; (4) penyampaian informasi materi, artinya kemampuan dalam menyampaikan informasi yang dipelajari secara individual; dan (5) proses encoding long-term memory (LTM) atau kemampuan menyimpan informasi jangka panjang. Penerapan kelima tahapan tersebut dalam pembelajaran Matematika disajikan pada tabel 1 .

Tabel 1

Blueprint Modul Mind Map dalam Pembelajaran Matematika

\begin{tabular}{|c|c|}
\hline Aspek & Indikator \\
\hline $\begin{array}{l}\text { Komunikasi tujuan } \\
\text { dan objektivitas }\end{array}$ & $\begin{array}{l}\text { a. Mengetahui pengertian metode belajar mind map. } \\
\text { b. Menyebutkan manfaat penggunaan mind map. } \\
\text { c. Mengidentifikasi dan memiliki gambaran proses belajar mind map pada pelajaran } \\
\text { Matematika. }\end{array}$ \\
\hline $\begin{array}{l}\text { Pemusatan } \\
\text { perhatian }\end{array}$ & $\begin{array}{l}\text { a. Memahami inti dari definisi dan jenis hubungan antar sudut (berpelurus dan } \\
\text { berpenyiku) yang disampaikan guru. } \\
\text { b. Memahami ciri sudut berpelurus dan berpenyiku yang telah disampaikan guru. }\end{array}$ \\
\hline $\begin{array}{l}\text { Organisasi dan } \\
\text { pemaknaan }\end{array}$ & $\begin{array}{l}\text { a. Menerapkan mind map pada catatan pribadi mengenai hubungan antar sudut } \\
\text { berpelurus dan berpenyiku. } \\
\text { b. Melengkapi mind map yang telah dibuat dengan ciri-ciri setiap jenis hubungan } \\
\text { antar sudut. } \\
\text { c. Mendiskusikan dengan kelompok untuk menyelesaikan soal hubungan antar sudut. } \\
\text { d. Siswa mampu membuat mind map secara berkelompok dan mempresentasikan di } \\
\text { depan kelas. }\end{array}$ \\
\hline $\begin{array}{l}\text { Penyampaian } \\
\text { informasi materi }\end{array}$ & $\begin{array}{l}\text { a. Siswa menerapkan mind map yang berisi penjelasan tentang sudut bertolak } \\
\text { belakang dan sudut dua garis sejajar } \\
\text { b. Siswa memahami langkah penyelesaian soal sudut bertolak belakang dan sudut dua } \\
\text { garis sejajar dengan menggunakan mind map } \\
\text { c. Siswa mampu membuat mind map secara individual berdasarkan soal sudut yang } \\
\text { ditentukan guru. } \\
\text { d. Siswa mempresentasikan di depan kelas hasil mind map yang telah dibuat. }\end{array}$ \\
\hline $\begin{array}{l}\text { Proses encoding } \\
\text { long-term memory } \\
\text { (LTM) }\end{array}$ & $\begin{array}{l}\text { a. Siswa mampu menyelesaikan soal terkait empat jenis sudut yang telah diajarkan } \\
\text { sebelumnya menggunakan mind map. } \\
\text { b. Siswa mempresentasikan di depan kelas hasil mind map yang telah dibuat. } \\
\text { c. Siswa dapat menyebutkan materi yang telah dipelajari dengan menekankan pada } \\
\text { definisi, jenis sudut, dan penyelesaian soal yang harus diingat siswa. } \\
\text { d. Siswa dapat menyelesaikan soal yang diberikan guru dan menjelaskan pada rekan } \\
\text { lain dengan metode mind map. }\end{array}$ \\
\hline
\end{tabular}


Selain lima tahap intervensi di atas, modul penerapan metode pembelajaran disusun berdasarkan teori mind map. Empat langkah yang dilakukan dalam proses pembelajaran berbasis mind map adalah: (1) overview, tinjauan menyeluruh terhadap suatu topik pada saat pembelajaran baru dimulai; (2) preview, tinjauan awal yang merupakan lanjutan dari overview berupa gambaran umum setingkat lebih detail sehingga siswa memiliki pemahaman tentang subtopik; (3) inview, tinjauan mendalam atau inti dari proses belajar dengan membahas suatu topik secara terperinci; (4) review, tinjauan ulang menjelang berakhirnya proses belajar mengajar dengan memberikan penekanan pada informasi, konsep, atau rumus yang harus diingat siswa.

Kegiatan yang berlangsung selain membuat mind map adalah diskusi kelompok, presentasi, dan modelling guru yang merupakan penerapan dari teori sosial kognitif. Fasilitator dalam intervensi ini adalah guru pelajaran Matematika serta observer yang mengamati jalannya proses intervensi.

Proses penelitian secara umum menggunakan kerangka kerja teori sosial kognitif dengan melibatkan observational learning (belajar melalui pengamatan) milik Bandura. Efikasi diri individu dapat meningkat melalui proses mengamati orang lain, terutama jika berada dalam situasi, karakteristik, dan mendapat tingkat kesulitan tugas yang sama (Bandura, 1997). Selama proses intervensi siswa berada dalam satu jenjang yang sama yaitu kelas VII SMP, situasi yang sama dalam pelajaran Matematika, dan memperoleh tugas baru berupa pelajaran Matematika dalam bentuk mind map. Siswa akan mengamati guru dalam menerapkan mind map serta mengamati lingkungan sekitar, dalam hal ini teman sekelas, ketika mengerjakan tugas mind map. Melalui proses pengamatan, siswa akan memperoleh pemahaman dan pengetahuan yang akan memengaruhi keyakinannya dalam pelajaran Matematika.

Analisis data dilakukan dengan tujuan menguji perbedaan perubahan rata-rata skor efikasi diri Matematika siswa dari pretest menuju posttest. Analisis data menggunakan repeated anova karena rancangan the one-group pretest-posttest design termasuk ke dalam rancangan within subject. Penelitian ini menggunakan dua kali pengukuran karena posttest hanya dilakukan satu kali dan tidak ada follow-up. Peningkatan efikasi diri Matematika dilihat dari tiga dimensi yaitu level, strength, dan generalization.

\section{Hasil Penelitian dan Pembahasan}

\section{Hasil Penelitian}

Hipotesis yang diajukan dalam penelitian ini adalah metode belajar visual mind map berpengaruh positif terhadap efikasi diri Matematika pada siswa kelas VII SMP Negeri X.

Sebelum menguji hipotesis penelitian, dilakukan analisis untuk mengetahui homogenitas kovarian skor efikasi diri Matematika antara pretest dan posttest. Hasil uji homogenitas Box's M menunjukkan angka .314 ( $p>.05)$ yang berarti kovarian skor efikasi diri Matematika kedua data homogen (Widhiarso, 2015).

Selain itu hasil uji normalitas pengukuran pretest dan posttest menunjukkan signifikasi diatas .01. Hasil skor signifikansi pretest adalah .984 sedangkan posttest sebesar .511. Kedua data efikasi diri Matematika dalam penelitian ini terdistribusi secara normal.

Tabel 2

Rasio Perbedaan Nilai $F$ dan Signifikansinya antara Rerata Skor Pretest dan Posttest

\begin{tabular}{lcccc}
\hline \multicolumn{5}{c}{ Mean } \\
Source & $d f$ & Square & $F$ & Sig. \\
\hline Time & 2 & 117.229 & 8.820 & .0001 \\
$\begin{array}{l}\text { Error } \\
\text { (time) }\end{array}$ & 66 & 13.292 & & \\
\hline
\end{tabular}


Tabel 3

Perbedaan Rerata dan Signifikansinya serta Besarnya Sumbangan Metode Belajar Visual Mind Map terhadap Efikasi Diri Matematika

\begin{tabular}{cccccc}
\hline Group & $T(I)$ & $T(J)$ & $M D(I-J)$ & Sig. & PES \\
\hline 1 & Pre & Post & -7.000 & .0001 & .574 \\
\hline
\end{tabular}

Hasil analisis menggunakan repeated anova menampilkan tabel tests of within subject effects untuk mengetahui perbedaan rerata skor sebelum dan sesudah pelaksanaan eksperimen antar individu dalam kelompok terdapat pada tabel 2 . Tabel 2 menunjukkan pada baris Time (pengukuran) dengan nilai $\mathrm{F}=8.820$ ( $\mathrm{p}<$ .01) yang berarti terdapat perbedaan sangat signifikan antara rata-rata skor pretest dengan rata-rata skor posttest. Sesuai dengan nilai yang ditunjukkan maka perubahan rata-rata skor pada saat pretest dan posttest berbeda, yang perbedaannya sebesar 7 poin (lihat tabel 3). Tanda negatif menunjukkan bahwa rata-rata skor posttest lebih tinggi daripada rata-rata skor pretest. Ini berarti pemberian intervensi metode belajar visual mind map dapat meningkatkan skor efikasi diri Matematika.

Uji analisis berikutnya dilakukan untuk memberikan informasi mengenai sumbangan efektif dari intervensi mind map yang telah dilakukan. Hasil analisis tertampil dalam tabel 3 .

Peningkatan efikasi diri Matematika yang dialami subjek nampak dari skor pretest menuju posttest $(\mathrm{MD}=-7.00 ; \mathrm{p}<$ .01). Hal ini menunjukkan metode belajar mind map yang digunakan siswa dapat meningkatkan efikasi diri Matematika secara signifikan. Sumbangan efektif intervensi dalam penelitian eksperimen dapat diketahui dari angka yang ditunjukkan oleh partial eta squared (PES).

Tabel 4

Rerata Skor Dimensi Efikasi Diri Matematika

\begin{tabular}{lccc}
\hline & Level & Generalization & Srength \\
\hline $\begin{array}{l}\text { Rerata } \\
\begin{array}{l}\text { Pretest } \\
\text { Rerata }\end{array}\end{array}$ & 50.7 & 47.5 & 52.7 \\
$\begin{array}{l}\text { Posttest } \\
\text { Selisih }\end{array}$ & 55.2 & 53.4 & 55.8 \\
\hline
\end{tabular}

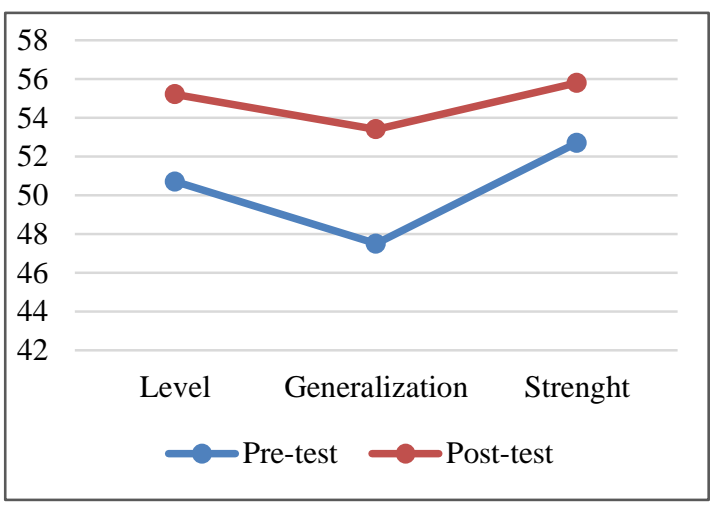

Gambar 1. Rerata skor dimensi efikasi diri Matematika

Intervensi mind map dalam penelitian ini memberikan kontribusi sebesar 57.4\% terhadap perubahan efikasi diri Matematika siswa kelas VII SMP. Perubahan rata-rata skor efikasi diri Matematika pada tiga dimensi efikasi diri Matematika disajikan pada tabel 4 .

Skor efikasi diri Matematika subjek mengalami peningkatan paling banyak pada dimensi generalization dengan selisih pretest-posttest sebesar 5.8. Dimensi generalization merujuk pada keyakinan siswa untuk berhasil dalam situasi dan materi Matematika. Di sisi lain peningkatan dimensi strength menunjukkan angka yang paling sedikit yaitu 3.1. Dimensi strength terkait dengan usaha yang dikerahkan siswa dalam melaksanakan tugas ataupun melakukan kegiatan akademik.

\section{Pembahasan}

Pembelajaran Matematika dengan strategi mind map dapat meningkatkan efikasi diri dibanding strategi konvensional (Sudjiono, 2014; Mariana, 2014). Perubahan tersebut terjadi karena efikasi diri merupakan aspek dinamis sehingga dapat berkembang apabila dilakukan manipulasi yang melibatkan sumbersumber efikasi diri (Bandura, 1997; Falco, 2019). Perbedaan penelitian ini dibanding penelitian sebelumnya (Sudjiono, 2014; Mariana, 2014) ialah penggunaan kerangka teori sosial kognitif dan adanya keterlibatan 
pembelajaran kelompok dalam proses intervensi yang dilakukan.

Selain itu salah satu hal yang membuat metode mengajar mind map efektif dalam meningkatkan efikasi diri ialah metode ini juga melibatkan pengaturan waktu dan manajemen usaha yang dilakukan siswa ketika mengikuti pelajaran (Tanriseven, 2014). Penggunaan warna, simbol, dan gambar membuat usaha siswa dalam menyerap pelajaran nampak lebih menyenangkan sehingga memudahkan dalam proses recall informasi. Subjek penelitian juga menyebutkan dengan mempelajari Matematika menggunakan mind map, siswa merasa tidak mudah bosan dan tidak kesulitan dalam memahami rumus ataupun soal yang diberikan. Selama intervensi berlangsung, siswa berpendapat bahwa Matematika tidak sesulit yang selama ini dipikirkan jika melalui metode yang menyenangkan dan berbeda dari sebelumnya.

Peningkatan efikasi diri siswa setelah memperoleh metode mind map pada pelajaran Matematika dalam penelitian ini dapat disebabkan beberapa hal. Pertama, struktur pembelajaran mind map serupa dengan struktur materi Matematika sehingga tepat untuk mengorganisir keterkaitan antar objek, rumus maupun hitungan (Loc \& Loc, 2020). Materi Matematika yang digunakan dalam penelitian ini adalah hubungan antar sudut. Bentuk materi yang sejak awal berupa gambar sangat membantu siswa dalam menyusun mind map yang digunakan untuk mencatat rumus maupun menyelesaikan soal.

Kedua, perubahan metode belajar di kelas tercatat lebih efektif dalam meningkatkan efikasi diri di bidang pelajaran dibandingkan dengan pelatihan (Ampofo, 2019; Adodo, 2013). Siswa sehari-hari dibiasakan menggunakan metode konvensional yang membuat cepat bosan. Selain itu karakteristik Matematika yang penuh dengan angka juga tidak selalu disukai oleh siswa. Selama proses intervensi dilakukan, siswa mendapatkan pengalaman baru melalui kegiatan mencatat dan menyelesaikan soal hitungan yang dikombinasikan dengan warna, gambar, dan simbol. Penggunaan warna dan kegiatan berkelompok membuat belajar menjadi lebih efisien, siswa menjadi lebih kreatif, dan mampu memusatkan perhatian sehingga memunculkan perasaan yakin pada kemampuan diri sendiri.

Ketiga, penggunaan mind map pada usia 11-13 tahun menunjukkan peningkatan secara kognitif dalam memproses informasi, menguraikan persoalan secara matematis, dan menciptakan lingkungan belajar yang kondusif (Merchie \& Keer, 2013). Karakteristik subjek penelitian ini mayoritas berusia 12 tahun yang masih membutuhkan stimulasi dari lingkungan untuk meningkatkan efikasi diri dalam proses pembelajaran (Bandura, 1997). Stimulus tersebut terwujud dalam mind map yang merangsang siswa menemukan cara efektif untuk mengeksplorasi ide kreatif dalam pemecahan masalah Matematika (Crowe \& Sheppard, 2012; Sudjiono, 2014).

Terdapat satu unsur penting yang memberi kontribusi dalam peningkatan keyakinan siswa yaitu dilibatkannya empat sumber efikasi diri selama intervensi berlangsung. Sumber pengalaman keberhasilan (enactive) diperoleh melalui kemudahan penerapan mind map dan pemberian apresiasi pada siswa yang berani mempresentasikan hasil kerjanya. Sumber pengalaman orang lain (vicarious) didapatkan ketika seorang siswa diberi apresiasi oleh guru, maka siswa tersebut dijadikan model dan acuan bagi siswa lain untuk menampilkan perilaku yang sama.

Sumber berikutnya yaitu adanya persuasi sosial ketika siswa menerima dorongan dari guru sebagai penyemangat. Persuasi dari teman sebaya dalam intervensi ini terdapat ketika siswa diberi tugas kelompok. Saat tugas kelompok, muncul kesadaran bahwa saat belajar bersama seluruh siswa berada dalam tahap 
pemahaman materi yang setara. Artinya, ketika ada seorang teman yang sanggup menyelesaikan soal maka siswa lain dapat menjadikannya contoh dalam proses dan langkah pengerjaannya. Sumber terakhir yang dilibatkan yaitu kondisi fisik dan emosional. Metode mind map membawa suasana belajar Matematika menjadi lebih bersemangat dan tidak membosankan. Suasana belajar yang berbeda membuat kondisi psikologis siswa lebih santai sehingga proses penyerapan informasi pun menjadi lebih efektif.

Situasi dalam dimensi generalization sangat erat kaitannya dengan metode belajar dan seluruh proses yang terjadi ketika siswa belajar Matematika. Ketika terjadi perubahan suatu metode yang biasa digunakan, maka konteks pembelajaran secara keseluruhan pun turut berubah. Dimensi generalization dalam penelitian ini memiliki dua indikator yaitu keyakinan dapat mengerjakan soal tanpa bantuan orang lain serta mampu memahami materi dalam berbagai kondisi.

Sejak awal pelaksanaan eksperimen, subjek penelitian telah mengalami perubahan situasi pembelajaran Matematika dari yang sebelumnya konvensional menjadi pembelajaran yang berbasis mind map. Siswa dapat mempersepsi bahwa situasi belajar mind map ternyata lebih menyenangkan dan dapat meningkatkan pemahamanan materi Matematika. Proses belajar yang berbeda dengan menggunakan kombinasi warna, diskusi kelompok, dan adanya apresiasi guru meningkatkan keyakinan siswa bahwa dirinya mampu memahami materi dan menyelesaikan soal tanpa bantuan orang lain.

Peningkatan pada dimensi generalization juga nampak dari respon siswa ketika ditugaskan untuk menggambarkan konsep rumus maupun penyelesaian soal Matematika menggunakan mind map baik secara berkelompok maupun individu. Siswa sangat antusias dalam berdiskusi, bekerjasama menciptakan mind map terbaik, dan melakukan elaborasi konsep materi hubungan antar sudut kemudian mempresentasikan di depan kelas. Siswa menjadi lebih bersemangat dengan menggunakan metode belajar secara visual seperti peta (map), grafik, atau model tiga dimensi untuk menggambarkan informasi (Snowman \& McCown, 2012). Penggunaan mind map dapat menjadikan proses pembelajaran menjadi lebih bermakna karena melibatkan aktivitas kognitif sekaligus sosial.

Pemahaman mengenai mind map diperoleh siswa melalui pengenalan pada kegiatan awal intervensi dan learning by doing selama pembelajaran berlangsung. Siswa yang paham mengenai konsep dasar mind map cenderung memiliki banyak ide, muncul perasaan antusias, dan rasa ingin tahu yang tinggi. Tiga hal tersebut dapat memunculkan perasaan mampu dan memengaruhi efikasi diri dalam menyelesaikan setiap tugas yang diberikan.

Keterbatasan dalam penelitian ini adalah belum dilakukan pembandingan terhadap kelompok kontrol. Keefektifan intervensi hanya berdasarkan pada perubahan skor yang terdapat dalam satu kelompok. Peneliti selanjutnya dapat mempertimbangkan bentuk alat ukur yang dapat memperkecil efek latihan sekaligus melakukan follow up untuk mengetahui ketahanan perubahan efikasi diri Matematika.

\section{Simpulan}

Sesuai dengan tujuan yang ingin dicapai dalam penelitian ini, hasil analisis menunjukkan adanya peningkatan efikasi diri Matematika pada subjek penelitian setelah mereka diberi metode belajar mind map. Penggunaan metode mind map menunjang siswa untuk memiliki pengalaman keberhasilan, belajar dari pengalaman siswa lain yang mampu menyelesaikan soal, memperoleh persuasi verbal yang positif dari guru maupun teman sebaya, dan menurunkan rasa cemas atau 
kondisi negatif lain ketika mempelajari Matematika.

\section{Daftar Pustaka}

Adhikari, K. (2020). Self-efficacy beliefs among school teachers mathematics of Nepal. International Journal of Research-Granthaalayah, 8(7), 192204.

https://doi.org/10.29121/granthaalayah. v8.i7.2020.694

Adodo, S. (2013). Effect of mind-mapping as a self-regulated learning strategy on students' achievement in basic science and technology. Mediterranean Journal of Social Sciences, 4(6), 163172.

https://doi.org/10.5901/mjss.2013.v4n6 p163

Ahmad, A., \& Triantoro, S. (2013). Effects of self-efficacy on students' academic performance. Journal of Educational, Health and Community Psychology, 2(1), 19-25. https://dx.doi.org/10.12928/jehcp.v2i1. 3740

Al-mehsin, S. (2017). Self-efficacy and its relationship with social skills and the quality of decision-making among the students of Prince Sattam Bin AbdulAziz University. International Education Studies, 10(7), 108-117. https://doi.org/10.5539/ies.v10n7p108

Ampofo, C. (2019). Relationship between pre-service teachers' mathematics selfefficacy and their mathematics achievement. African Journal of Educational Studies in Mathematics and Sciences, 15(1), 23-36. https://doi.org/10.4314/ajesms.v15i1.3

Bandura, A. (1997). Self-efficacy: The exercise of control. W. H. Reeman and Company.

Basith, A., Syahputra, A., \& Ichwanto, M. (2020). Academic self-efficacy as predictor of academic achievement. Jurnal Pendidikan Indonesia, 9(1), 163-170. https://dx.doi.org/10.23887/jpi-

undiksha.v9i1.24403

Bire, A., Geradus, U., \& Bire, J. (2014). Pengaruh gaya belajar visual, auditorial, dan kinestetik terhadap prestasi belajar siswa. Jurnal Kependidikan, 44(2), 168-174. https://doi.org/10.21831/jk.v44i2.5307

Cheema, J. (2018). Effect of math-specific self-efficacy on math literacy: Evidence from a Greek survey. Research in Education, 102(1), 13-36. https://doi.org/10.1177/003452371774 1914

Crowe, M., \& Sheppard, L. (2012). Mind mapping research methods. Qualitative Quantitative, 46(1), 1493-1504. https://doi.org/10.1007/s11135-0119463-8

Dhindsa, H. S., Makarimi-Kasim, \& Anderson, O. R. (2011). Constructivist-visual mind map teaching approach and the quality of students' cognitive structures. Journal of Science Educational Technology, 20(1), 186-200. https://dx.doi.org/10.1007/s10956-0109245-4

Falco, L. (2019). An intervention to support mathematics self-efficacy in middle school. Middle School Journal, 50(2), 28-44.

https://doi.org/10.1080/00940771.2019 .1576580

Hanifah, Waluya, S., Rochmad, \& Wardono. (2020). Mathematical representation ability and self-efficacy. Journal of Physics: Conference Series, 1613 , 1-6. https://doi.org/10.1088/17426596/1613/1/012062

Hastjarjo, T. D. (2019). Rancangan eksperimen-kuasi. Buletin Psikologi, 27(2), 187-203. https://doi.org/10.22146/buletinpsikolo gi.38619

Hughes, E. M., \& Riccomini, P. J. (2011). Mathematics motivation and self- 
efficacy of middle school students. Focus on Middle School, 24(1), 1-6.

Joseph, D. (2019). Mathematics anxiety and self-efficacy: A phenomenological dimension. Journal of Humanities and Education Development, 1, 22-34.

Köseoğlu, Y. (2015). Self-efficacy and academic achievement-A case from Turkey. Journal of Education and Practice, 6, 131-141.

Kudo, H., \& Mori, K. (2015). A preliminary study of increasing selfefficacy in junior high school students: Induced success and a vicarious experience. Psychological Reports, 117(2), 631-642. https://doi.org/10.2466/11.07.PR0.117 c22z4

Kurniati, A., Fransiska, \& Sari, A. W. (2019). Analisis gaya belajar siswa pada mata pelajaran bahasa Indonesia kelas V sekolah dasar negeri 14 manis raya kecamatan Sepauk tahun pelajaran 2018/2019. Jurnal Pendidikan Dasar Perkhasa, 5(1), 87-103. https://doi.org/10.31932/jpdp.v5i1.362

Loc, N., \& Loc, M. (2020). Using mind map in teaching mathematics: An experimental study. International Journal of Scientific \& Technology Research, 9(4), 1149-1155.

Lu, T., \& Yang, X. (2018). Effects of the visual or verbal learning style on concentration and achievement in mobile learning. Eurasia Journal of Mathematics, Science and Technology Education, 14(5), 1719-1729. https://doi.org/10.29333/ejmste/85110

Mariana, S. (2014). Pendekatan scientific disertai mind map untuk meningkatkan kemampuan pemahaman konsep dan koneksi matematis serta self-efficacy siswa SMP (Tesis tidak diterbitkan). Universitas Pendidikan Indonesia Bandung.

Martin, D., \& Rimm-Kaufman, S. (2015). Do student self-efficacy and teacherstudent interaction quality contribute to emotional and social engagement in fifth grade math?. Journal of School Psychology, 53, 359-373. https://doi.org/10.1016/j.jsp.2015.07.0 01

Merchie, E., \& Keer, H. (2013). Schematizing and processing informational texts with mind maps in fifth and sixth grade. Middle Grades Research Journal, 8(3), 61-81.

Polat, O., Yavuz, E., \& Tunc, A. (2017). The effect of using mind maps on the development of maths and science skills. Cypriot Journal of Educational Sciences, $\quad 12(1), \quad 32-45$. https://doi.org/10.18844/cjes.v12i1.120 1

Qudsyi, H. (2012). Keterlibatan orang tua dan efikasi diri Matematika dan prediksinya terhadap kemampuan Matematika pada siswa SD. Universitas Gadjah Mada.

Recber, S., Isiksal, M., \& Koç, Y. (2018). Investigating self-efficacy, anxiety, attitudes and mathematics achievement regarding gender and school type. Anales De Psicología, 34(1), 41-51. https://doi.org/10.6018/analesps.34.1.2 29571

Rochmad, Bintang, G. M., \& Arifudin, R. (2014). Mind mapping learning to increase mathematical reflective thinking ability of junior high school students. International Conference on Mathematics, Science, and Education 2014 (ICMSE 2014) (pp. 17-22). Faculty of Mathematics and natural Sciences Semarang State University. https://icmseunnes.com/2015/wpcontent/uploads/2015/10/4.pdf

Sahabuddin, R., Thaha, S., \& Nurjaya, F. (2018). Effects of visual learning style and school climate on students' achievement of learning entrepreneurship at SMKN 1 Palangga. Journal of Entrepreneurship Education, 21(3), 1-13.

Siswanti, D., \& Djalal, N. (2018). The effect of self-efficacy to mathematical anxiety on junior high school students 
of YDM learning guidance course Makassar. Proceedings of the 3rd ASEAN Conference on Psychology, Counselling, and Humanities (ACPCH 2017)

https://dx.doi.org/10.2991/acpch17.2018 .3

Snowman, J., \& McCown, R. (2012). Psychology applied to teaching (13th edition). Cengage Learning.

Sudjiono. (2014). Pengaruh mind mapping terhadap peningkatan efikasi diri Matematika dan prestasi belajar Matematika siswa SMP (Disertasi tidak diteerbitkan). Universitas Gadjah Mada.

Tanriseven, I. (2014). A tool that can be effective in the self-regulated learning of pre-service teachers: The mind map. Australian Journal of Teacher education, $\quad 39(1), \quad 65-80$. https://doi.org/10.14221/ajte.2014v39n 1.1

Tee, T. K., Azman, M. N., Mohamed, S., Muhammad, M., Mohamad, M. M., Yunos, J. M., . . O Othman, W. (2014). Buzan mind mapping: An efficient techniques for note-taking. International Journal of Social, Human Science, and Engineering, $8(1), \quad 28-31 . \quad$ https://doi.org/ 10.5281/zenodo. 1336202

Warsihna, J., Ramdani, Z., \& Tae, L. F. (2021). The measurement of science teaching efficacy belief instrument (STEBI): Sustaining teacher's quality. Psychology and Education, 58(3), 2972-2979. https://doi.org/10.17762/pae.v58i3.438 0

Warner, L., \& French, D. (2020). Selfefficacy interventions. Dalam $M$. Hagger, L. Cameron, K. Hamilton, N. Hankonen, \& T. Lintunen (Eds.), The Handbook of Behavior Change (Hal. 461-478). Cambridge University Press.

Widhiarso, W. (2015, Januari 11). Aplikasi anava campuran untuk penelitian eksperimen. widhiarso.staff.ugm.ac.id: http://widhiarso.staff.ugm.ac.id/

files/Aplikasi\%20Anava\%20Mixed $\% 2$

0Design\%20untuk\%20Eksperimenrevised\%202011.pdf

Widiana, I., \& Jampel, I. (2016). Improving students' creative thinking and achievement through the implementation of multiple intelligence approach with mind mapping. International Journal of Evaluation and Research in Education, 5(3), 246-254. https://doi.org/10.11591/ijere.v5i3.454 6 